\title{
Survei Pelaksanaan Pembelajaran PJOK pada Masa Pandemi Covid-19
}

\author{
Ida Bagus Made Arga Parta ${ }^{*}$, I Nyoman Kanca², Ni Putu Dwi Sucita Dartini ${ }^{3}$
}

1,2,3 Prodi Pendidikan Jasmani Kesehatan dan Rekreasi, Universitas Pendidikan Ganesha, Singaraja, Indonesia

\section{ART ICLE INFO \\ Article history: \\ Received August 24, 2021 \\ Revised August 26, 2021 \\ Accepted September 19, 2021 \\ Available online October 25, 2021 \\ Kata Kunci: \\ Pelaksanaan, Pembelajaran \\ PJOK, Masa Pandemi \\ Keywords: \\ Implementation, PJOK Learning, Pandemic Period

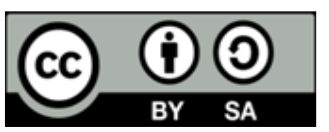 \\ This is an open access article under the CC BY-SA license. \\ Copyright $(2021$ by Author. Published by Universitas Pendidikan Ganesha.}

\begin{abstract}
A B S T R A K
Perubahan proses pembelajaran dari tatap muka menjadi pembelajaran daring merupakan hal yang baru.. dan tentu saja terdapat hal-hal yang menjadi kendala dalam pelaksanaanya. Tujuan dari penelitian ini yaitu untuk mengetahui pelaksanaan pembelajaran PJOK pada masa pandemi Covid-19. Jenis penelitian ini yaitu penelitian deskriptif kuantitatif dengan metode survei. Sampel dalam penelitian ini yaitu guru sebanyak 8 responden dan peserta didik sebanyak 87 responden. Metode pengumpulan data yang digunakan yaitu menggunakan kuesioner yang dibuat dari indikator pelaksanaan pembelajaran dan disebarkan secara online di sekolah yang menjadi sampel penelitian ini. Teknik analisis data yang digunakan dalam penelitian ini adalah analisis deskriptif. Hasil penelitian menunjukkan bahwa pelaksanaan pembelajaran PJOK di SMP Negeri se-Kecamatan Bebandem berada pada kategori efektif untuk guru dengan persentase $50 \%$ dan persentase untuk peserta didik $71,26 \%$ yang masuk pada kategori efektif. Diharapkan agar tetap meningkatkan pembelajaran yang diberikan kepada peserta didik bisa melalui metode pengajaran yang berbeda atau belajar sambil bermain maupun melalui kompetensi dasarnya disederhanakan agar mudah diajarkan pada siswa.
\end{abstract}

\section{A B S T RAK}

Changing the learning process from face-to-face to online learning is a new thing. Some things become obstacles in its implementation. This study aimed to determine the implementation of PJOK learning during the Covid-19 pandemic. The type of this research is descriptive quantitative research with a survey method. The sample in this study were teachers with as many as eight respondents and students as many as 87 respondents. The data collection method used was a questionnaire made from indicators of learning implementation and distributed online in the schools that were the sample of this study. The data analysis technique used in this research is descriptive analysis. The results showed that the implementation of PJOK learning in public junior high schools throughout the Burdendem District was in the practical category for teachers with a percentage of $50 \%$ and $71.26 \%$ for students in the practical category. It is hoped that to continue to improve the learning provided to students. It can be through different teaching methods or learning while playing or through simplified essential competencies so that they are easily taught to students.

\section{PENDAHULUAN}

Pembelajaran merupakan bantuan yang diberikan pendidik agar dapat terjadi proses perolehan ilmu dan pengetahuan, penguasaan kemahiran dan tabiat, serta pembentukan sikap dan kepercayaan pada peserta didik (Arimbawa, Astra, \& Satyawan, 2017; Rosdiani, 2013). Pembelajaran adalah proses interaksi yang dilakukan secara sadar oleh peserta didik dan sumber belajar pada suatu lingkungan belajar untuk mewujudkan tujuan pendidikan (Mulya \& Lengkana, 2020; Triwardhani, Trigartanti, Rachmawati, \& Putra, 2020). Keberhasilan dari suatu kegiatan pembelajaran dapat dilihat dari hasil belajar serta sikap peserta didik setelah mengikuti pembelajaran (Nurlia, Hala, Muchtar, Jumadi, \& Taiyeb, 2017; Yesiana, Gading, \& Riastini, 2016). Untuk mewujudkan hal tersebut proses pembelajaran dalam satuan pendidikan harus diselenggarakan dengan sebaik-baiknya (Moma, 2017; Nada, Utaminingsih, \& Ardianti, 2018). 
Namun kenyataan saat ini, proses pembelajaran mengalami perubahan. Hal ini disebabkan adanya pandemi covid-19. Pandemi covid-19 ini disebabkan oleh oleh Severe Acute Respiratory Syndrome Coronavirus-2 (SARS-CoV-2) yaitu virus yang menyerang sistem pernapasan (Putri \& Purwanto, 2020; Susilo et al., 2020). Cara yang dilakukan pemerintah untuk menekan penyebaran Covid19 di Indonesia adalah dengan pembatasan fisik atau Physical Distancing. Pembatasan menimbulkan banyak perubahan aspek sosial, ekonomi, budaya, bahkan pendidikan (Prayitno \& Mardianto, 2020). Kebijakan dalam bidang pendidikan yaitu penutupan sekolah sehingga sistem pengajaran harus beralih dari pelajaran tatap muka menjadi model pembelajaran daring (Jamilah, 2020; Napitupulu, 2020; Quezada, Talbot, \& Quezada-Parker, 2020). Pembelajaran daring merupakan pemanfaatan jaringan internet dalam proses pembelajaran. Pembelajaran daring membuat siswa memiliki keleluasaan waktu belajar, dapat belajar kapanpun dan dimanapun. Siswa dapat berinteraksi dengan guru menggunakan beberapa aplikasi seperti classroom, video converence, live chat, zoom, telepon maupun melalui whatsapp group (Anugrahana, 2020; Pratiwi, 2020). Saat ini semua proses pembelajaran dilaksanakan secara daring, tidak terkecuali pelajaran Pendidikan Jasmani Olahraga dan Kesehatan (PJOK).

Pembelajaran PJOK adalah pelajaran dengan banyak aktivitas gerak seperti berlari, melempar, memukul, dan melompat dimana biasanya mata pelajaran ini didominasi dengan banyak praktik dibandingkan teori (Pamungkas \& Hariyoko, 2018). Pembelajaran PJOK bertujuan untuk mengembangkan aspek kebugaran jasmani, keterampilan gerak, stabilitas emosional, aspek pola hidup sehat, dan pengenalan lingkungan bersih pada peserta didik melalui berbagai aktivitas olahraga. (Haris, 2018; Putra, Artanayasa, \& Suwiwa, 2020) Pendidikan jasmani bukan hanya ditujukan untuk mengembangkan kemampuan psikomotorik, akan tetapi juga mengembangkan kemampuan kognitif dan afektif peserta didik (Hanief \& Sugito, 2015; Paramitha, 2018). Keberhasilan pembelajaran PJOK dapat dilihat dari kemampuan serta pemahaman peserta didik terhadap materi yang diajarkan. Saat situasi pembelajaran seperti sekarang ini penting bagi tenaga pendidik mampu menciptakan proses belajar yang menyenangkan, efektif dan mampu diikuti oleh semua peserta didik (Fadillah \& Bilda, 2019; Pratiwi, 2020).

Namun berdasarkan hasil wawancara perubahan pelaksanaan pembelajaran konvensional menjadi pembelajaran daring memiliki beberapa hambatan, diantaranya kendala sinyal yang tidak stabil karena ada siswa yang tinggal di daerah dengan jangkauan sinyal yang kurang terjangkau, terkadang ada siswa yang tidak memiliki paket data internet sehingga pemberian informasi pembelajaran PJOK menjadi terhambat. Tidak semua tempat tersedia fasilitas internet (berkaitan dengan masalah tersedianya listrik, telepon, dan komputer) (Saifulloh \& Darwis, 2020; Simanjuntak, Kismartini, Dwimawanti, \& Hidayatullah, 2020). Selain itu pemberian materi dan tugas lebih banyak membaca karena bila memberikan tugas praktik yang divideokan akan sulit dikarenakan keterbatasan paket data internet dan sinyal, oleh karena itu tidak semua materi bisa berjalan sesuai rencana pelaksanaan pembelajaran (RPP) karena menyesuaikan dengan keadaan siswa. Menurut salah satu siswa SMP Negeri di Kecamatan Bebandem, pembelajaran daring pada mata pelajaran PJOK kurang menarik karena siswa hanya diberikan tugas. Kendala-kendala itu akan menghambat peserta didik untuk belajar sehingga akan berpengaruh terhadap motivasi dan hasil belajar peserta didik.

Perubahan sistem pembelajaran dari tatap muka menjadi pembelajaran daring membawa dampak yang beragam. Tentu ada dampak positif dan negatifnya. Dampak positif dari pembelajaran daring tentu mampu mengurangi penyebaran virus corono, juga dengan siswa belajar di rumah akan memberikan kesempatan bagi orang tua untuk lebih dekat dan memperhatikan anaknya. Namun seperti hasil wawancara tentu banyak kendala yang dialami selama pembelajaran daring baik oleh guru dan peserta didik. Oleh Karena itu penting untuk dilakasakana survey atau penelitian untuk mengetahui bagaimana proses pelaksanaan pembelajaran PJOK selama masa pandemi covid-19. Penelitian oleh (Raibowo \& Nopiyanto, 2020) menunjukan bahwa proses belajar mengajar PJOK di masa pandemi covid19 berada pada kategori rendah. Penelitian oleh (Firman, F., \& Rahayu, 2020) menunjukkan pembelajaran online memiliki fleksibilitas dalam pelaksanaannya dan mampu mendorong munculnya kemandirian belajar dan motivasi untuk lebih aktif dalam belajar. Penelitian lain yang dilakukan oleh (Sukriadi \& Arif, 2020) menunjukkan Pelaksanaan Pembelajaran Pendidikan Jasmani Adaptif di SLB C Provinsi DKI Jakarta tahun 2019 dalam kategori cukup.

Penelitian ini bertujuan untuk mengetahui pelaksanaan pembelajaran PJOK pada masa pandemi Covid-19 di SMP Negeri se-Kecamatan Bebandem Kabupaten Karangasem Bali. Penelitian ini sangat penting dilaksanakan mengingat bahwa PJOK adalah salah satu mata pelajaran yang penting harus dilaksanakan oleh seluruh peserta didik. Dengan dilaksanakannya proses pembelajarn PJOK di masa pandemi ini diharapkan siswa lebih aktif untuk melaksanakan olahraga dirumah sehingga siswa memiliki daya tahan tubuh yang baik dan terhindar dari virus dan penyakit. 


\section{METODE}

Penelitian ini menggunakan desain penelitian deskriptif kuantitatif dengan metode survei. Metode yang akan digunakan dalam mengumpulkan data suatu metode survey yaitu menggunakan observasi ,wawancara dan dokumentasi. Peneliti akan menggunakan kuesioner online melalui google form. Google form merupakan aplikasi administrasi survei yang sangat berguna bagi peneliti google from menawarkan kemudahan serta keefisienan untuk membuat sebuah survei penelitian dengan pertanyaan yang dapat disesuaikan dengan kebutuhan penelitian. Dalam penelitian sebuah sampel dapat di gunakan sabagai alat pengumpulan data. Sampel dapat mewakil dari populasi yang akan di teliti. Sampel merupakan bagian dari jumlah dan karakteristik yang dimiliki populasi, maka dari itu peneliti dalam pengambilan sampel menggunakan simple random sampling yang di lakukan secara acak untuk peserta didik dan total sampling untuk guru. Bedasarkan pendapat tersebut sampel peserta didik yang di gunakan dalam penelitian ini menggunakan rumus Slovin dalam (Arikunto, 2006) adalah 87 peserta didik. Dengan sampel guru berjumlah 8 orang guru. Instrumen dalam penelitian ini merupakan instrumen pelaksanaan pembelajaran yang diadopsi dari RPP yang meliputi aspek pendahuluan, pelaksanaan, dan penutup. Kisikisi instrument dapat dilihat pada Tabel 1.

Tabel 1. Kisi-Kisi Instrumen Penelitian untuk Guru dan Peserta didik

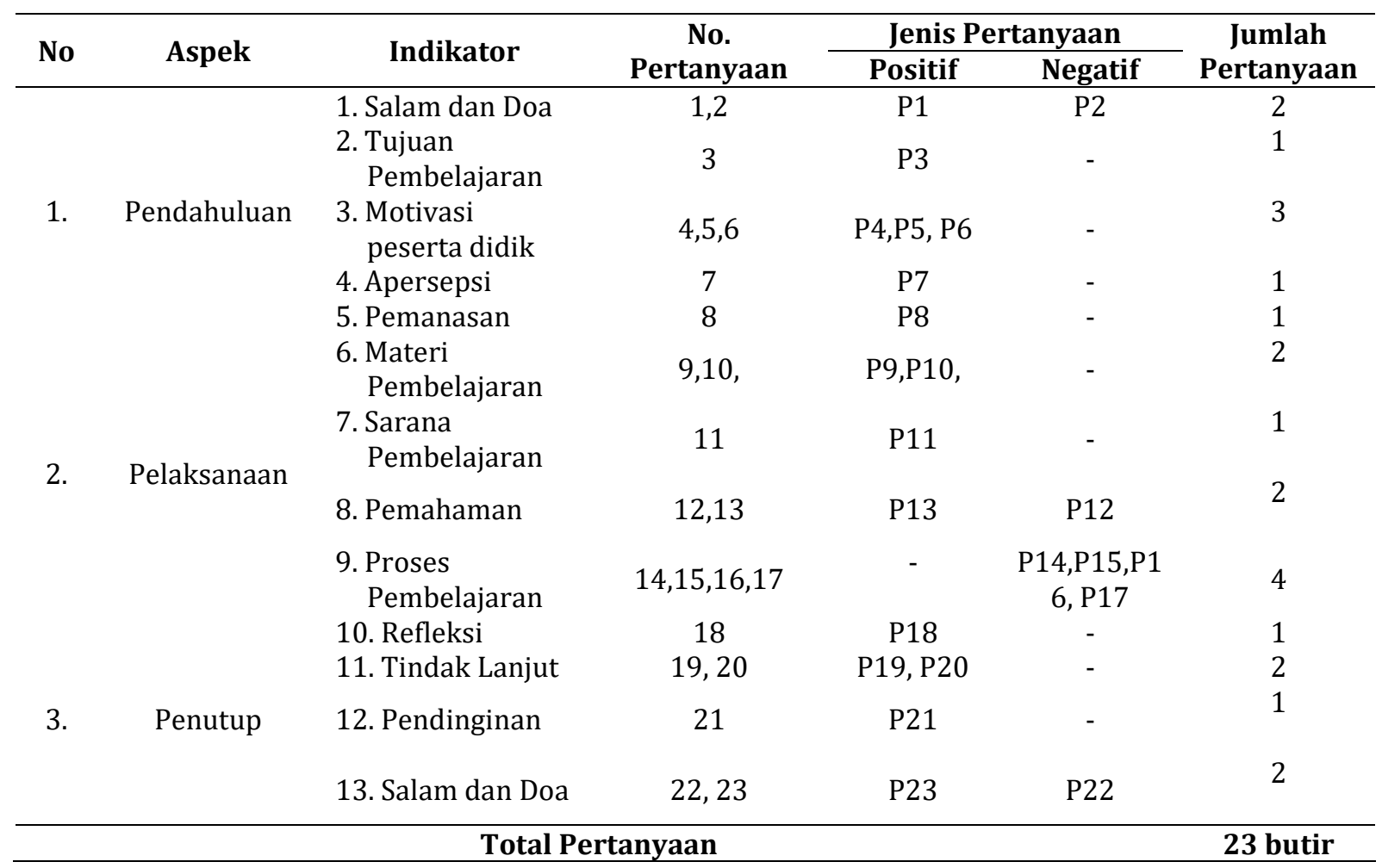

Angket atau daftar pertanyaan di khususkan untuk peserta didik dan guru yang berada di SMP N se-Kecamatan Bebandem yang berjumlah 87 peserta didik dan 8 orang guru. Wawancara di khusukan untuk guru yang berada di SMP N se-Kecamatan Bebandem. Populasi dalam penelitian ini adalah seluruh guru PJOK di SMP Negeri se-Kecamatan Bebandem yang berjumlah 8 orang guru dan 656 orang peserta didik kelas VIII dari 4 SMP Negeri di kecamatan Bebandem. Menyusun butir-butir pertanyaan merupakan sebuah langkah terakhir dari penyusunan angket atau kuesioner dan daftar pertanyaan wawancara. Butir pertanyaan harus merupakan penjabaran dari isi faktor-faktor yang sudah diuraikan, sehingga dapat membatasi butir-butir soal yaitu disusun dari suatu faktor yang bersangkutan kemudian dijabarkan menjadi indikator-indikator. Pengukuran pelaksanaan pembelajaran PJOK pada masa pandemi dalam penelitian ini adalah dengan menggunakan skala likert poin 1 - 4. Teknik Analisis data menggunakan rumus rata-rata yaitu jumlah skor responden dibagi dengan jumlah responden. 


\section{HASIL DAN PEMBAHASAN}

Hasil

Analisis dari pendapat guru dan peserta didik tentang pelaksanaan pembelajaran diperoleh dengan jumlah pertanyaan sebanyak 23 butir soal dengan nilai maksimum sebesar 92 dan nilai minimum 23. Data selanjutnya dikategorikan sesuai dengan sesuai dengan rumus yang pengkategoriannya sesuai dengan rumus yang pengkategoriannya dibagi menjadi lima yaitu sangat efektif, efektif, cukup efektif, kurang efektif, dan tidak efektif. Pelaksanaan Pembelajaran PJOK pada masa pandemi di SMP Negeri seKecamatan Bebandem telah diukur menggunakan angket yang terdiri dari 23 butir pernyataan. Dari hasil analisis data yang telah dilakukan, terhadap pelaksanaan pembelajaran guru, maka diperoleh rerata sebesar 71,13, median sebesar 75, Modus sebesar 75, dan standar deviasi ideal sebesar 8,94.

Tabel 2. Hasil Analisis Pelaksanaan Pembelajaran PJOK pada Masa Pandemi di SMP Negeri Se-Kecamatan Bebandem untuk Guru

\begin{tabular}{ccc}
\hline Interval & Frekuensi & Kategori \\
\hline $79-92$ & 1 & Sangat Efektif \\
$65-78$ & 4 & Efektif \\
$51-64$ & 3 & Cukup Efektif \\
$37-50$ & 0 & Kurang Efektif \\
$23-36$ & 0 & Tidak Efektif \\
\hline Total & $\mathbf{8}$ & \\
\hline
\end{tabular}

Berdasarkan Tabel 2, diketahui bahwa 1 orang guru masuk dalam kategori sangat efektif, 4 orang guru masuk dalam kategori efektif, 3 orang guru masuk dalam kategori cukup efektif, dan tidak ada guru masuk dalam kategori kurang efektif dan kategori tidak efektif. Apabila dilihat dari rata-rata skor responden yang dimasukkan kedalam skala penilaian kategori, maka dapat diketahui pelaksanaan pembelajaran PJOK pada masa pandemi Covid-19 di SMP Negeri se-Kecamatan Bebandem berada dalam kategori Efektif.

Sedangkan untuk peserta didik diperoleh rerata sebesar 70,20, median sebesar 70, Modus sebesar 76, dan standar deviasi ideal sebesar 7,36. Distribusi frekuensi pengkategorian dapat dilihat pada Tabel 3.

Tabel 3. Hasil Analisis Pelaksanaan Pembelajaran PJOK Pada Masa Pandemi di SMP Negeri Se-Kecamatan Bebandem untuk Peserta Didik

\begin{tabular}{ccc}
\hline Interval & Frekuensi & Kategori \\
\hline $79-92$ & 7 & Sangat Efektif \\
$65-78$ & 62 & Efektif \\
$51-64$ & 17 & Cukup Efektif \\
$37-50$ & 1 & Kurang Efektif \\
$23-36$ & 0 & Tidak Efektif \\
\hline Total & $\mathbf{8 7}$ & \\
\hline
\end{tabular}

Untuk peserta didik diketahui bahwa 7 orang peserta didik masuk dalam kategori sangat efektif, 62 orang peserta didik masuk dalam kategori efektif, 17 orang peserta didik masuk dalam kategori cukup efektif, 1 orang peserta didik masuk dalam kategori kurang efektif, serta tidak ada peserta didik masuk dalam kategori tidak efektif. Apabila dilihat dari rata-rata skor responden yang dimasukkan kedalam skala penilaian kategori, maka dapat diketahui pelaksanaan pembelajaran PJOK pada masa pandemi Covid-19 di SMP Negeri se-Kecamatan Bebandem berada dalam kategori Efektif.

Di Dalam Penelitian ini terdapat metode wawancara yang dimana tujuan metode wawancara ini untuk mengetahui pendapat guru tentang pelaksanaan pembelajaran PJOK daring dan kendala-kendala yang dihadapi. Metode wawancara ditujukan kepada guru PJOK. Berdasarkan hasil penelitian dan wawancara yang telah dilakukan kepada guru PJOK, ada beberapa pertanyaan yang terkait dengan pendapat guru dan kendala yang dihadapi selama pelaksanaan pembelajaran daring dari rumah.

Dari hasil wawancara bersama guru PJOK di SMP Negeri se-Kecamatan Bebandem terkait kendala-kendala dan kesiapan saat pembelajaran daring, terlihat bahwa guru cukup kesulitan dalam pelaksanaan pembelajaran dimana dalam pembuatan materi supaya mudah dimengerti oleh peserta didik melalui grup Whatsapp karena proses pembelajaran daring dengan pembelajaran tatap muka sangat jauh berbeda apalagi pembelajaran PJOK kebanyakan praktik di lapangan namun dengan pembelajaran daring 
kebanyakan peserta didik hanya memahami teori saja. Dalam pelaksanaan pembelajaran daring dapat berjalan sesuai jadwal dengan tepat waktu namun sering terkendala pada jaringan internet yang tidak stabil, pelaksanaan pembelajaran akan berjalan efektif apabila sinyal sedang bagus, selain itu peserta didik juga terkendala pada kuota internet yang terbatas dan bahkan ada peserta didik yang belum memiliki gadget/Smartphone sehingga harus pergi ke rumah temannya untuk belajar bersama peserta didik lainnya. Maka untuk mengatasi hal tersebut guru meleluasakan peserta didik untuk mengumpulkan tugas ke sekolah namun tetap menggunakan prokes yang ketat.

\section{Pembahasan}

Berdasarkan hasil penelitian, dapat disimpulkan bahwa menggunakan survey pelaksanakan pembelajaran PJOK ini dapat membantu jalannya penelitian, dari hasil yang dilihat dari tabel 1 dapat dikatakan bahwa pembelajaran berjalan efektif, hal ini dibuktikan dengan rata-rata skor yang dimasukkan ke dalam skala penilaian kategori menyatakan pelaksanaan pembelajaran PJOK pada masa pandemi COVID-19 di SMP Negeri Se-Kecamatan Bebandem Kabupaten Karangasem untuk guru berjalan efektif. Pada penelitian ini ada beberapa indikator pertanyaan yang menyatakan bahwa proses pembelajaran PJOK secara daring berjalan dengan efektif, seperti indikator guru memulai pembelajaran dengan tepat waktu, yang terdapat dalam aspek pendahuluan. Sejalan dengan penelitian yang dilakukan (Agustini, Kristiantari, \& Putra, 2016) (Putra, 2017) menunjukkan bahwa proses belajar mengajar guru di SD Negeri Kedungsari 1 melaksanakan kegiatan belajar mengajar penjaskesrek secara umum sangat baik.

Indikator lain yang masuk kategori efektif adalah guru memberikan materi menggunakan media pembelajaran. Media pembelajaran adalah salah satu komponen keberhasilan proses pembelajaran (Pakpahan \& Fitriani, 2020; Prabawa \& Restami, 2020). Dengan bantuan media pembelajaran guru akan lebih mudah dalam menyampaikan materi (Lestari \& Projosantoso, 2016). Penelitian oleh (Sadikin, A., \& Hamidah, 2020) menunjukkan bahwa media pembelajaran yang digunakan saat pembelajaran daring adalah media pembelajaran yang dapat diakses menggunakan layanan internet. Sehingga dengan bantuan internet pengetahuan yang dapat di terima oleh peserta didik juga lebih beragam.

Proses pembelajaran PJOK pada masa pandemi tentu menjadi tantangan tersendiri untuk guru dan peserta didik. Oleh karenanya pada proses pembelajaran yang dilaksanakan secara daring guru harus mampu menciptakan proses belajar yang menyenangkan dan efektif guna membangun minat dan motivasi peserta didik dalam belajar. Selain itu guru harus bekerja sama dengan orang tua. Karena peran orang tua sangat penting saat pembelajaran daring yaitu untuk mengawasi siswa dan membimbing siswa selama belajar di rumah (Primasari \& Zulela, 2021; Yulianingsih, Suhanadji, Nugroho, \& Mustakim, 2020). Survei dilaksanakan guna mengetahui kendala yang dialami oleh guru dan peserta didik dalam proses pembelajaran. Penelitian yang dilakukan oleh (Wulandari, I. G. A. A., \& Agustika, 2020) menunjukkan bahwa persepsi mahasiswa terhadap pembelajaran daring bersifat positif artinya mahasiswa memberikan respon yang baik dan positif tentang pembelajaran secara daring. Penelitian yang dilakukan oleh (Hasanah, Raodatun, I Putu Panca Adi, 2021) bahwa pembelajaran PJOK secara daring pada masa pandemi covid-19 termasuk dalam kategori baik, dan dilihat dari garis besar pendahuluan, inti dan penutup pembelajaran sudah berjalan dengan cukup baik. Penelitian oleh (Dewi, Ririn Purnama, 2021) menunjukkan bahwa bahwa pembelajaran daring dapat mempermudah proses pembelajaran pada masa pandemi covid-19.

\section{SIMPULAN DAN SARAN}

Berdasarkan hasil penelitian, maka simpulan dari penelitian ini adalah guru dalam pelaksanaan pembelajaran PJOK daring di SMP se-Kecamatan Bebandem sudah terlaksana efektif, hal ini dapat dilihat dari hasil analisis rata-rata pertanyaan guru yang diperoleh dengan kategori efektif, kemudian untuk pendapat peserta didik pelaksanaan pembelajaran PJOK pada masa pandemi Covid-19 di SMP Negeri SeKecamatan Bebandem Kabupaten Karangasem Bali masih terkategori efektif dilaksanakan pada peserta didik dengan melihat hasil rata-rata pertanyaan. Implikasi dari penelitian ini yakni sebagai masukan pada guru PJOK bahwa ketersediaan RPP daring, penggunaan aplikasi internet, media pembelajaran, materi pembelajaran PJOK, manajemen waktu yang lengkap pada saat pembelajaran daring penting untuk kesuksesan berlangsungnya pembelajaran serta pemahaman siswa terhadap materi PJOK, kepada peserta didik agar semangat dan bersikap jujur dalam mengikuti pembelajaran dan menjawab soal yang diberikan oleh guru dalam keadaan apapun, karena kejujuran dapat menciptakan keadilan untuk membangun pendidikan yang lebih bermartabat sehingga mampu tercipta sebuah karakter anak bangsa yang lebih maju. 


\section{DAFTAR RUJUKAN}

Agustini, P. P., Kristiantari, M. . R., \& Putra, D. K. N. S. (2016). Penerapan Model Pembelajaran Berbasis Masalah Berbantuan Media Audio Visual Untuk Meningkatkan Hasil Belajar Keterampilan Menyimak Tema Sejarah Peradaban Indonesia Pada Siswa Kelas V Sdn 8 Sumerta. MIMBAR PGSD Undiksha, 4(1). https://doi.org/10.23887/jjpgsd.v4i1.7265.

Anugrahana, A. (2020). Hambatan, Solusi dan Harapan: Pembelajaran Daring Selama Masa Pandemi Covid-19 Oleh Guru Sekolah Dasar. Scholaria: Jurnal Pendidikan Dan Kebudayaan, 10(3), 282-289. https://doi.org/10.24246/j.js.2020.v10.i3.p282-289.

Arikunto. (2006). Prosedur Penelitian Suatu Pendekatan Praktik. jakarta: PT Rineka Cipta.

Arimbawa, I. G. A. A., Astra, I. K. B., \& Satyawan, I. M. (2017). Pengaruh Penerapan Model Pembelajaran Kooperatif Tipe STAD Berbantuan Media Gambar Terhadap Hasil Belajar Teknik Dasar Passing Sepak Bola. Jurnal Pendidikan Jasmani,Olahraga Dan Kesehatan Undiksha, 5(2), 1-9. https://ejournal.upi.edu/index.php/SpoRTIVE/article/view/13369.

Dewi, Ririn Purnama, S. (2021). Minat Siswa SMP Terhadap Pembelajaran PJOK Secara Daring Pada Masa New Normal. Physical Activity Journal (PAJU), 2(2), 205-215. http://jos.unsoed.ac.id/index.php/paju/article/view/3988.

Fadillah, A., \& Bilda, W. (2019). Pengembangan Video Pembelajaran Matematika Berbatuan Aplikasi Sparkoll Videoscribe. Jurnal Gantang, 4(2), 177-182. https://doi.org/10.31629/jg.v4i2.1369.

Firman, F., \& Rahayu, S. (2020). Pembelajaran Online di Tengah Pandemi Covid-19. Indonesian Journal of Educational Science (IJES), 2(2), 81-89. https://doi.org/10.31605/ijes.v2i2.659.

Hanief, Y. N., \& Sugito, S. (2015). Membentuk Gerak Dasar Pada Siswa Sekolah Dasar Melalui Permainan Tradisional. Jurnal SPORTIF: Jurnal Penelitian Pembelajaran, 1(1), 100-113. https://doi.org/10.29407/js_unpgri.v1i1.575.

Haris, I. N. (2018). Model pembelajaran peer teaching dalam pembelajaran pendidikan jasmani. Journal of $\begin{array}{llll}\text { Chemical Information and } & \text { Modeling, }\end{array}$ https://ejournal.unsub.ac.id/index.php/FKIP/article/download/191/170.

Hasanah, Raodatun, I Putu Panca Adi, I. G. S. (2021). Survey Pelaksaan Pembelajaran Pjok Secara Daring Pada Masa Pandemi Covid-19 Nurul. Jurnal Kejaora: Jurnal Kesehatan Jasmani Dan Olah Raga, 6(1), 189-196. https://ejournal.unibabwi.ac.id/index.php/kejaora/article/view/1295.

Jamilah. (2020). Guru profesional di era new normal: Review peluang dan tantangan dalam pembelajaran daring. Premiere Educandum: Jurnal Pendidikan Dasar Dan Pembelajaran, 10(2), 238-247. https://doi.org/10.25273/pe.v10i2.7494.

Lestari, D. I., \& Projosantoso, A. K. (2016). Pengembangan Media Komik IPA Model PBL untuk Meningkatkan Kemampuan Berfikir Analitis dan Sikap Ilmiah Developing Science Comic Media Using the Problem-Based Learning Model to Increase the Analytical Thinking Ability and Scientific Attitude. Jurnal Inovasi Pendidikan IPA, 2(2), 145-155. https://doi.org/10.21831/jipi.v2i2.7280.

Moma. (2017). Pengembangan Kemampuan Berpikir Kreatif dan Pemecahan Masalah Matematis Mahasiswa Melalui Metode Diskusi. Cakrawala Pendidikan, 36(1), 130-139.

Mulya, G., \& Lengkana, A. S. (2020). Pengaruh Kepercayaan Diri, Motivasi Belajar Terhadap Prestasi Belajar Pendidikan Jasmani. COMPETITOR: Jurnal Pendidikan Kepelatihan Olahraga, 12(2), 83. https://doi.org/10.26858/cjpko.v12i2.13781.

Nada, I., Utaminingsih, S., \& Ardianti, S. D. (2018). Penerapan Model Open Ended Problems Berbantuan Cd Pembelajaran Untuk Meningkatkan Kemampuan Berpikir Kreatif Siswa Kelas Iv Sd 1 Golantepus. Jurnal Pendidikan Sekolah Dasar, 4(2), 216. https://doi.org/10.30870/jpsd.v4i2.3856.

Napitupulu, R. M. (2020). Dampak pandemi Covid-19 terhadap kepuasan pembelajaran jarak jauh. Jurnal Inovasi Teknologi Pendidikan, 7(1), 23-33. https://doi.org/10.21831/jitp.v7i1.32771.

Nurlia, Hala, Muchtar, Jumadi, \& Taiyeb. (2017). Hubungan Antara Gaya Belajar, Kemandirian Belajar, Dan Minat Belajar Dengan Hasil Belajar Biologi Siswa. Jurnal Pendidikan Biologi, 6(2). https://doi.org/https://doi.org/10.24114/jpb.v6i2.6552.

Pakpahan, R., \& Fitriani, Y. (2020). Analisa Pemafaatan Teknologi Informasi Dalam Pemeblajaran Jarak Jauh Di Tengah Pandemi Virus Corona Covid-19. JISAMAR (Journal of Information System, Applied, Management, Accounting and Researh), 4(2), 30-36. http://journal.stmikjayakarta.ac.id/index.php/jisamar/article/view/181.

Pamungkas, T. S., \& Hariyoko. (2018). Pengaruh Metode Drill Dan Metode Barrier Hops Terhadap Hasil Belajar Shooting. Gelanggang Pendidikan Jasmani Indonesia, 2(1), 46-51. https://doi.org/10.17977/um040v2i1p46-51.

Paramitha, S. T. (2018). Revitalisasi Pendidikan Jasmani untuk Anak Usia Dini melalui Penerapan Model $\begin{array}{lllll}\text { Bermain } & \text { Edukatif } & \text { Blam. }\end{array}$ 
https://ejournal.upi.edu/index.php/penjas/article/view/2018-04-05/0.

Prabawa, D. G. A. P., \& Restami, M. P. (2020). Pengembangan Multimedia Tematik Berpendekatan Saintifik untuk Siswa Sekolah Dasar. Mimbar PGSD Undikhsa, 8(3), 479-491. https://ejournal.undiksha.ac.id/index.php/JJPGSD/article/view/28970.

Pratiwi, E. W. (2020). Dampak Covid-19 Terhadap Kegiatan Pembelajaran Online Di Perguruan Tinggi Kristen Di Indonesia. Perspektif Ilmu Pendidikan, 34(1), 1-8. https://doi.org/10.21009/pip.341.1.

Prayitno, \& Mardianto, M. F. F. (2020). Peningkatan Hasil Evaluasi Pembelajaran Daring Saat Pandemi Covid-19 Berdasarkan Media Powerpoint Interaktif. MUST: Journal of Mathematics Education, Science and Technology, 5(2), 171-181. https://doi.org/10.30651/must.v5i2.6119.

Primasari, I. F. N. D., \& Zulela. (2021). Kendala Pembelajaran Jarak Jauh (PJJ) Secara Online Selama Masa Pandemik Covid-19 di Sekolah Dasar. JIKAP PGSD: Jurnal Ilmiah Ilmu Kependidikan, 5(1), 64-73. https://doi.org/10.26858/jkp.v5i1.16820.

Putra, G. N. K. W., Artanayasa, I. W., \& Suwiwa, I. G. (2020). Pengaruh Modelpembelajaran Kooperatif Tipe Numbered Head Together Berbantuan Media Gambar Terhadap Hasil Belajar Teknik Dasar Passing Bola Voli. Jurnal Ilmu Keolahragaan Undiksha, 8(3), 164-172. https://doi.org/10.23887/jiku.v8i3.29823.

Putri, R. S., \& Purwanto, D. (2020). Impact of the COVID-19 pandemic on online home learning: An explorative study of primary schools in Indonesia. International ,. Journal of Advanced Science and Technology, 29(5), 4809-4818.

Quezada, R. L., Talbot, C., \& Quezada-Parker, K. B. (2020). From Bricks and Mortar to Remote Teaching: A Teacher Education Program's Response to COVID-19. Journal of Education for Teaching, 46(4), 472-483. https://doi.org/10.1080/02607476.2020.1801330.

Raibowo, S., \& Nopiyanto, Y. E. (2020). Proses Belajar Mengajar Pjok Di Masa Pandemi Covid-19. STAND : Journal Sports Teaching and Development, 1(2), 112-119. https://doi.org/10.36456/jstand.v1i2.2774.

Rosdiani, D. (2013). Perencanaan Pembelajaran Dalam Pendidikan Jasmani Dan Kesehatan. (J. Husdarta, Ed.). Bandung: Alfabeta.

Sadikin, A., \& Hamidah, A. (2020). Pembelajaran Daring di Tengah Wabah Covid-19. Biodik, 6(2), 109-119. https://doi.org/10.22437/bio.v6i2.9759.

Saifulloh, A. M., \& Darwis, M. (2020). Manajemen Pembelajaran dalam Meningkatkan Efektivitas Proses Belajar Mengajar di Masa Pandemi Covid-19. Bidayatuna: Jurnal Pendidikan Guru Mandrasah Ibtidaiyah, 3(2), 285. https://doi.org/10.36835/bidayatuna.v3i2.638.

Simanjuntak, S. Y., Kismartini, Dwimawanti, I. H., \& Hidayatullah, M. A. (2020). Respons Guru Terhadap Kebijakan Pembelajaran Jarak Jauh Selama Pandemi Covid-19. Jurnal Ilmiah Pendidikan Citra Bakti, 7(2), 125-136. https://doi.org/10.38048/jipcb.v7i2.108.

Sukriadi, S., \& Arif, M. (2020). Survei Pelaksanaan Pembelajaran Pendidikan Jasmani Adaptif Di Slb C Provinsi Dki Jakarta Tahun 2019. Jurnal Ilmiah Sport Coaching and Education Vol . 4 Januari 2020, 4. http://journal.unj.ac.id/unj/index.php/jsce/article/view/14552.

Susilo, A., Rumende, C. M., Pitoyo, C. W., Santoso, W. D., Yulianti, M., Herikurniawan, H., ... Yunihastuti, E. (2020). Coronavirus Disease 2019: Tinjauan Literatur Terkini. Jurnal Penyakit Dalam Indonesia, 7(1), 45. https://doi.org/10.7454/jpdi.v7i1.415.

Triwardhani, I. J., Trigartanti, W., Rachmawati, I., \& Putra, R. P. (2020). Strategi Guru dalam membangun komunikasi dengan Orang Tua Siswa di Sekolah. Jurnal Kajian Komunikasi, 8(1), 99. https://doi.org/10.24198/jkk.v8i1.23620.

Wulandari, I. G. A. A., \& Agustika, G. N. S. (2020). Dramatik Pembelajaran Daring Pada Masa Pandemi Covid-19 (Studi Pada Persepsi Mahasiswa PGSD Undiksha). Mimbar PGSD Undiksha, 8(3), 515526. https://ejournal.undiksha.ac.id/index.php/JJPGSD/article/view/29259.

Yesiana, P. F., Gading, I. K., \& Riastini, P. N. (2016). Pengaruh Model Pembelajaran Make A Match Terhadap Hasil Belajar IPA Siswa Kelas V SD Negeri Gugus IV Kabupaten Buleleng Tahun Pelajaran 2016/2017. Mimbar PGSD Undiksha, 6(3), 1-11. https://doi.org/http://dx.doi.org/10.23887/jjpgsd.v5i2.10938.

Yulianingsih, W., Suhanadji, S., Nugroho, R., \& Mustakim, M. (2020). Keterlibatan Orangtua dalam Pendampingan Belajar Anak selama Masa Pandemi Covid-19. Jurnal Obsesi : Jurnal Pendidikan Anak Usia Dini, 5(2), 1138-1150. https://doi.org/10.31004/obsesi.v5i2.740. 